\title{
PENGARUH PENDAPATAN RUMAH TANGGA DAN PENGELUARAN RUMAH TANGGA TERHADAP STABILITAS KEUANGAN RUMAH TANGGA PADA PELAKU WIRAUSAHA DI OBYEK WISATA DANAU CIPONDOH
}

\author{
Heny Ratnaningtyas \\ Email: heny.ratnaningtyas@ stptrisakti.ac.id \\ Prodi S1 Pariwisata, Sekolah Tinggi Pariwisata Trisakti \\ Jl. IKPN Bintaro No. 1, Pesanggrahan, Tanah Kusir, Jakarta \\ Nurbaeti \\ Email: nurbaeti@stptrisakti.ac.id \\ Prodi S2 Pariwisata, Sekolah Tinggi Pariwisata Trisakti \\ Jl. IKPN Bintaro No. 1, Pesanggrahan, Tanah Kusir, Jakarta \\ Anita Swantari \\ Email: anitaswantari@ stptrisaktiac.id \\ Prodi D4 Perhotelan, Sekolah Tinggi Pariwisata Trisakti \\ Jl. IKPN Bintaro No. 1, Pesanggrahan, Tanah Kusir, Jakarta
}

\begin{abstract}
ABSTRAK
Penelitian ini bertujuan untuk mengetahui pendapatan rumah tangga dan pengeluaran rumah tangga terhadap stabilitas keuangan rumah tangga pada pelaku wirausaha di obyek wisata Danau Cipondoh. Metode yang digunakan dalam penelitian ini adalah analisis regresi berganda dengan menggunakan bantuan program Eviews 7. Teknik pengambilan sampel dalam penelitian ini adalah sampling jenuh, dimana populasi sama dengan sampel yaitu berjumlah 31 orang dengan menyebarkan kuisioner kepada pelaku wirausaha yang ada di Obyek Wisata Danau Cipondoh. Hasil penelitian menunjukkan bahwa variabel pendapatan rumah tangga dan pengeluaran rumah tangga secara parsial berpengaruh signifikan terhadap variabel stabilitas keuangan rumah tangga. Sementara nilai Adjusted $\mathrm{R}^{2}$ yang didapat sebesar $83,41 \%$, yang menunjukan bahwa kemampuan variabel bahwa variabel pendapatan rumah tangga dan pengeluaran rumah tangga dalam menjelaskan variabel stabilitas keuangan dalam rumah tangga adalah sebesar 83,41\%, sisanya sebesar $16,59 \%$, dijelaskan oleh variabel lain di luar penelitian ini.
\end{abstract}

Kata Kunci: Pendapatan Rumah Tangga, Pengeluaran Rumah Tangga, Stabilitas Keuangan Dalam Rumah Tangga

\begin{abstract}
This study aims to determine household income and household expenditure on financial stability in the household of entrepreneurs in Lake Cipondoh tourism objects. The sample in this study amounted to 31 people by distributing questionnaires to entrepreneurs in Cipondoh Lake Tourism Object. The method used in this research is multiple regression analysis using the Eviews 7 program. The results of the multiple regression equation research show that the variables of household income and household expenditure partially have a significant effect on the variable of household financial stability. Meanwhile, the adjusted $\mathrm{R} 2$ value is $83.41 \%$, which indicates that the variable ability of household income and household expenses in explaining household financial stability variables is $\mathbf{8 3 . 4 1 \%}$, the remaining $16.59 \%$ is explained by other variables outside of this study.
\end{abstract}

Keywords: Household Income, Household Expenditures and Financial Stability in Households 


\section{PENDAHULUAN}

Rumah tangga dalam memenuhi kebutuhannya harus memiliki penghasilan untuk memperoleh barang atau jasa. Sumber pendapatan rumah tangga berasal dari gaji dan penghasilan yang lainnya. Dalam memenuhi kebutuhannya, rumah tangga harus mengeluarkan dana untuk mendapatkan barang atau jasa. Besar kecilnya konsumsi rumah tangga dapat dilihat dari jenis, kuantitas, dan tingkat harga barang atau jasa yang dibutuhkan. Pemenuhan kebutuhan rumah tangga yang rasional didasari oleh akal sehat dan harus bersikap selektif dalam membeli barang atau jasa. Dalam membeli barang atau jasa, rumah tangga harus memperhatikan kepentingan seluruh anggota rumah tangga dan ketersediaan dana (Tigau et al, 2017).

Masalah utama rumah tangga adalah keuangan, bagaimana rumah tangga dapat mengelola sisa pendapatan yang telah dikeluarkan. Dengan kata lain bagaimana membangun keuangan rumah tangga dengan sebaik-baiknya. Jika rumah tangga telah berhasil dalam keuangannya, maka dapat dikatakan bahwa rumah tangga tersebut berhasil dan sukses secara finansial. Mengelola keuangan rumah tangga dengan baik adalah salah satu kunci sukses mengatur manajemen keuangan rumah tangga. Mengelola keuangan rumah tangga lebih sulit dari pada mengelola keuangan pribadi karena melibatkan suami, istri dan anak (Hatidjah et al, 2016).

Jika pengelolaan keuangan rumah tangga dilakukan dengan baik, maka anggota rumah tangga tersebut beruntung. Namun apabila salah mengelola, maka rumah tangga akan mengalami masalah keuangan bahkan sebelum gaji bulanan diterima lagi, rumah tangga akan mengalami masalah keuangan terus menerus. Rumah tangga harus memahami kebutuhan dan keinginan, kebutuhan rumah tangga adalah pengeluaran rutin yang dikeluarkan dan wajib harus dipenuhi untuk membeli kebutuhan primer setiap bulannya seperti sandang, pangan, papan dan pendidikan anak. Sedangkan keinginan rumah tangga adalah sesuatu yang dibeli oleh rumah tangga tetapi tidak berdasarkan kebutuhan yang wajib dipenuhi seperti kebutuhan sekunder dan tersier, kebutuhan sekunder dan tersier akan terpenuhi apabila kebutuhan primer sudah dipenuhi dengan baik. Oleh karena itu rumah tangga harus mampu menghitung pendapatan dan pengeluarannya, pastikan pengeluaran rutin rumah tangga tidak besar dari pendapatan yang diterimanya, pangkas kebutuhan yang tidak penting. Kemudian sisihkan sisa pendapatan dengan menabung untuk dijadikan kebutuhan yang tidak terduga di masa depan. Membantu keuangan rumah 
tangga penting dilakukan, karena keuangan rumah tangga secara kuantitas dan kualitas akan bermanfaat bagi rumah tangga untuk mencapai rumah tangga sejahtera, yang terpenuhi secara material dan spiritual, dan seluruh anggota rumah tangga dapat mengembangkan potensinya sesuai dengan bakat dan kemampuannya (Masithoh et al, 2016).

Dengan sistem pengelolaan keuangan rumah tangga yang baik dipastikan stabilitas sistem keuangan rumah tangga aman dan terkendali. Stabilitas sistem keuangan rumah tangga tidak hanya untuk rencana jangka pendek tetapi juga untuk keuangan jangka panjang dan itu yang lebih penting. Sehingga beberapa cara yang harus diperhatikan oleh rumah tangga khususnya pasangan suami istri adalah dengan saling mendukung dan mengkomunikasikan terlebih dahulu bagaimana uang masing-masing. Baru setelah itu mereka dapat menggunakan sistem manajemen untuk stabilitas sistem keuangan rumah tangga (Arnesih, 2016; Ratnaningtyas, 2021).

Sektor rumah tangga memiliki kekuatan untuk mempengaruhi perekonomian dan memainkan peran penting dalam stabilitas moneter dan keuangan terkait perilaku rumah tangga terhadap alokasi sumber dayanya, termasuk keputusan menabung dan belanja, yang dapat mempengaruhi harga pasar. Rumah tangga dalam kondisi surplus akan mengalokasikan dana berlebih untuk sejumlah aset keuangan dan aset tetap. Dalam kondisi defisit, rumah tangga akan mencari sumber pembiayaan untuk konsumsi dan investasi. Oleh karena itu, kesehatan sektor rumah tangga dapat mempengaruhi kesehatan perbankan dan sistem keuangan suatu negara. Pengaruh sektor rumah tangga terhadap sistem keuangan dapat dilihat dari kualitas aset bank berupa pinjaman kepada rumah tangga (Rakhmawati \& Suhadi, 2017; Devita et al, 2021).

Pendapatan dan konsumsi rumah tangga semaksimal mungkin dapat mendukung pemenuhan kebutuhan yang pada akhirnya akan menentukan tingkat kesejahteraan keluarga. Menerima penghasilan bisa dilakukan dengan ikhlas dalam menekuni pekerjaan yang sedang dijalankan. Sehingga penghasilan yang maksimal akan mampu memenuhi kebutuhan keluarga dan dapat mencapai tingkat kesejahteraan keluarga yang diinginkan. Penghasilan yang diperoleh tidak hanya diukur dari nilai rupiah tetapi nilai upah riil yang digunakan sebagai ukuran kemampuan upah untuk dapat membeli barang dan jasa (Amanaturohim \& Widodo, 2016). 


\section{METODE PENELITIAN}

Penelitian ini menggunakan metode analisis regresi berganda dengan bantuan software Eviews 7. Objek yang diambil dalam penelitian ini adalah para pelaku wirausaha di objek wisata Danau Cipondoh. Data yang digunakan dalam penelitian ini adalah data kualitatif yaitu jenis data yang disajikan berupa kata-kata verbal bukan berupa angka yaitu berupa kuisioner yang diberikan oleh pelaku wirausaha di objek wisata Danau Cipondoh. Dalam penelitian ini sumber data primer adalah data atau informasi yang diperoleh langsung peneliti dari observasi lapangan mengenai variabel penelitian. Berkaitan dengan peneliti, yang peneliti lakukan adalah mengumpulkan beberapa kuesioner yang diisi oleh responden. Teknik pengambilan sampel yang digunakan adalah teknik sampling jenuh karena populasinya sama dengan sampel pada metode 31 pelaku wirausaha di obyek wisata Danau Cipondoh. Persamaan regresi linier berganda penelitian ini:

$\mathrm{SKRT}=\mathrm{a}+\beta_{1} \mathrm{PDRT}+\beta_{2} \mathrm{PGRT}+\mathrm{e}$

Keterangan:

PDRT $=$ Pendapatan Rumah Tangga

PGRT $=$ Pengeluaran Rumah Tangga

SKRT $=$ Stabilitas Keuangan Rumah Tangga

$\mathrm{a}=$ Bilangan Konstanta

$\beta=$ Koefisien Regresi

\section{Definisi Operasional dan Pengukuran Variabel}

Variabel yang digunakan dalam penelitian ini terdiri dari 2 (dua) variabel bebas yaitu pendapatan rumah tangga dan pengeluaran rumah tangga, dan 1 (satu) variabel terikat yaitu stabilitas keuangan rumah tangga

1. Pendapatan Rumah Tangga

Pendapatan rumah tangga adalah pendapatan seluruh anggota keluarga yang berkaitan dengan pemenuhan kebutuhan bersama atau individu dalam rumah tangga (Afrida, 2003). Pendapatan rumah tangga dapat diperoleh dari seluruh anggota rumah tangga, baik dari kepala keluarga maupun seluruh anggota keluarga (Junandar, 2004). Pendapatan keluarga adalah imbalan atas pekerjaan atau jasa atau imbalan yang diperoleh karena kontribusi yang diberikan dalam kegiatan produksi. Pendapatan keluarga meliputi: (1) Gaji, diperoleh dari pendapatan yang tetap dihasilkan tiap bulan oleh pegawai tetap; (2) Upah, diperoleh dari faktor produksi berupa tenaga kerja 
lepas/harian; (3) Sewa, diperoleh dari faktor produksi berupa tanah/bangunan; (4) Bunga, diperoleh dari faktor produksi berupa simpanan/tabungan; (5) Laba, diperoleh dari faktor produksi berupa keahlian dan modal (Gilarso, 2008).

2. Pengeluaran Rumah Tangga

Pengeluaran rumah tangga adalah penggunaan barang dan jasa yang secara langsung akan memenuhi kebutuhan rumah tangga (Rosyidi, 2009). Pengeluaran rumah tangga merupakan pengeluaran barang dan jasa oleh rumah tangga. Barang yang termasuk pembelian rumah tangga pada barang yang mudah rusak seperti kendaraan, barang rumah tangga, dan barang yang tidak mudah rusak seperti makanan dan pakaian. Jasa meliputi barang tidak berwujud seperti potong rambut, jasa kesehatan (Mankiw, 2007). Pengeluaran keluarga meliputi: (1) Membeli barang-barang keperluan sehari-hari seperti makanan, minuman dan pakaian; (2) Membayar tagihan listrik dan air; (3) membayar biaya anak sekolah; (4) Membeli BBM atau membayar transportasi umum; (5) Membeli mobil, perhiasan, dan peralatan elektronik (OJK, 2020).

3. Stabilitas Keuangan Rumah Tangga

Stabilitas keuangan rumah tangga adalah bagaimana keuangan rumah tangga dapat dikelola dengan baik dan benar, sehingga dapat dipastikan keuangan dalam suatu rumah tangga aman dan terkendali, dimana keuangan rumah tangga dapat diatur dengan cermat melalui tahap perencanaan, kerjasama anggota pelaku rumah tangga, pelaksanaan, pengarahan dan pengawasan (Manullang, 2004).

Pengukuran variabel dalam penelitian ini menggunakan skala likert yang terdiri dari: 1 = Sangat Tidak Setuju; 2 = Tidak Setuju; 3 = Setuju; 4 = Sangat Setuju.

\section{HASIL DAN PEMBAHASAN}

\section{HASIL}

Tabel 1. Uji Validitas

\begin{tabular}{|c|c|c|c|}
\hline Variabel & Indikator Pertanyaan & r-hitung & r-tabel \\
\hline \multirow{3}{*}{ Pendapatan Rumah Tangga } & PDRT $_{1}$ & 0,6121 & 0,2913 \\
\cline { 2 - 4 } & PDRT $_{2}$ & 0,7603 & 0,2913 \\
\cline { 2 - 4 } & PDRT $_{3}$ & 0,6554 & 0,2913 \\
\cline { 2 - 4 } & PDRT $_{4}$ & 0,7121 & 0,2913 \\
\cline { 2 - 4 } & PDRT $_{5}$ & 0,7044 & 0,2913 \\
\hline \multirow{2}{*}{$\begin{array}{c}\text { Pengeluaran Rumah } \\
\text { Tangga }\end{array}$} & PGRT $_{1}$ & 0,6188 & 0,2913 \\
\cline { 2 - 4 } & PGRT $_{2}$ & 0,6295 & 0,2913 \\
\cline { 2 - 4 } & PGRT $_{3}$ & 0,6109 & 0,2913 \\
\hline
\end{tabular}




\begin{tabular}{|c|c|c|c|}
\hline Variabel & Indikator Pertanyaan & r-hitung & r-tabel \\
\hline \multirow{4}{*}{$\begin{array}{c}\text { Stabilitas Keuangan } \\
\text { Rumah Tangga }\end{array}$} & $\mathrm{PGRT}$ & 0,7534 & 0,2913 \\
\cline { 2 - 4 } & $\mathrm{PGRT}_{5}$ & 0,7027 & 0,2913 \\
\cline { 2 - 4 } & $\mathrm{SKRT}_{1}$ & 0,6531 & 0,2913 \\
\cline { 2 - 4 } & $\mathrm{SKRT}_{2}$ & 0,6119 & 0,2913 \\
\cline { 2 - 4 } & $\mathrm{SKRT}_{3}$ & 0,8124 & 0,2913 \\
\cline { 2 - 4 } & $\mathrm{SKRT}_{4}$ & 0,7392 & 0,2913 \\
\cline { 2 - 4 } & $\mathrm{SKRT}_{5}$ & 0,8766 & 0,2913 \\
\hline
\end{tabular}

Sumber: Data diolah dengan Microsoft Excel (2020)

Tabel di atas menunjukkan bahwa semua indikator pertanyaan adalah valid, hal ini ditandai dengan semua nilai r-hitung > r-tabel $(0,2913)$.

Tabel 2. Uji Reliabilitas

\begin{tabular}{|c|c|c|c|}
\hline Variabel & Indikator Pertanyaan & r-hitung & Nilai Alpha \\
\hline Pendapatan Rumah Tangga & PDRT & 0,7953 & 0,60 \\
\hline Pengeluaran Rumah Tangga & PGRT & 0,7117 & 0,60 \\
\hline Stabilitas Keuangan RumahTangga & SKRT & 0,8268 & 0,60 \\
\hline
\end{tabular}

Sumber: Data diolah dengan Microsoft Excel (2020)

Tabel di atas menunjukkan bahwa semua indikator adalah valid, hal ini ditandai dengan semua nilai r-hitung > nilai cronbach alpha $(0,60)$.

Tabel 3. Uji Multikolinieritas

\begin{tabular}{cccc}
\hline \hline Variable & $\begin{array}{c}\text { Coefficient } \\
\text { Variance }\end{array}$ & $\begin{array}{c}\text { Uncentered } \\
\text { VIF }\end{array}$ & $\begin{array}{c}\text { Centered } \\
\text { VIF }\end{array}$ \\
\hline \hline C & 0.093109 & 16.31557 & NA \\
PDRT & 0.000817 & 5.647115 & 1.475793 \\
PGRT & 0.007216 & 19.51946 & 1.475793 \\
\hline \hline
\end{tabular}

Sumber: Data diolah dengan Eviews 7 (2020)

Tabel di atas menunjukkan nilai Centered VIF untuk variabel PDRT (pendapatan rumah tangga) dan PGRT (pengeluaran rumah tangga) adalah 1,349 tidak ada yang lebih besar dari 10 atau 5, maka dapat dikatakan tidak terjadi multikolinieritas pada kedua variabel bebas tersebut.

Tabel 4. Uji Heteroskedastisitas

\begin{tabular}{ll}
\hline \hline Prob. F(2,122) & 0.1554 \\
Prob. Chi-Square(2) & 0.1219 \\
Prob. Chi-Square(2) & 0.1117 \\
\hline \hline
\end{tabular}

Sumber: Data diolah dengan Eviews 7 (2020) 
Tabel di atas menunjukkan Nilai Prob. F hitung sebesar 0,1554 lebih besar dari tingkat alpha $0,05(5 \%)$ sehingga, berdasarkan uji hipotesis maka tidak terjadi heteroskedastisitas.

Tabel 5. Uji Autokorelasi

\begin{tabular}{lrll}
\hline \hline R-squared & 0.848809 & Mean dependent var & 3.264512 \\
Adjusted R-squared & 0.845031 & S.D. dependent var & 1.816530 \\
S.E. of regression & 0.792051 & Akaike info criterion & 2.715156 \\
Sum squared resid & 71.12587 & Schwarz criterion & 2.532371 \\
Log likelihood & -158.0025 & Hannan-Quinn criter. & 2.165776 \\
F-statistic & 52.09754 & Durbin-Watson stat & 1.729033 \\
Prob(F-statistic) & 0.000000 & & \\
\hline \hline
\end{tabular}

Sumber: Data diolah dengan Eviews 7 (2020)

Jumlah variabel bebas: $\mathrm{k}=2$ Jumlah sampel $: \mathrm{n}=31$. Tabel Durbin-Watson menunjukkan bahwa nilai $\mathrm{dL}=1,297$ dan nilai $\mathrm{dU}=1,570$. Nilai $\mathrm{DW}$ hitung sebesar 1,729 nilai tersebut berada diantara dU dan (4-dU) yaitu 1,570 $<1,729<2,430$, sehingga tidak ada masalah autokorelasi.

Tabel 6. Uji t

\begin{tabular}{crrrr}
\hline \hline Variable & Coefficient & Std. Error & t-Statistic & Prob. \\
\hline \hline C & -1.153205 & 0.150354 & -3.755227 & 0.0000 \\
PDRT & 0.371620 & 0.022162 & 12.15341 & 0.0000 \\
PGRT & 0.513231 & 0.057327 & 5.221009 & 0.0000 \\
\hline \hline
\end{tabular}

Sumber: Data diolah dengan Eviews 7 (2020)

Untuk variabel pendapatan rumah tangga, nilai t-hitung $(12,153)>\mathrm{t}$-tabel $(1.696)$ dan nilai probabilitas $0,0000>0,05$. Dengan demikian $\mathrm{H}_{0}$ ditolak dan $\mathrm{H}_{1}$ diterima yang artinya bahwa pendapatan rumah tangga secara parsial berpengaruh signifikan terhadap stabilitas keuangan rumah tangga.

Untuk variabel pengeluaran rumah tangga, nilai t-hitung $(5,221)<\mathrm{t}$-tabel $(1.696))$ dan nilai probabilitas $0,0000<0,05$. Dengan demikian $\mathrm{H}_{0}$ ditolak dan $\mathrm{H}_{2}$ diterima yang artinya bahwa pengeluaran rumah tangga secara parsial berpengaruh signifikan terhadap stabilitas keuangan rumah tangga.

Tabel 7. Uji F

\begin{tabular}{llll}
\hline \hline R-squared & 0.848809 & Mean dependent var & 3.264512 \\
Adjusted R-squared & 0.845031 & S.D. dependent var & 1.816530
\end{tabular}




\begin{tabular}{lrll} 
S.E. of regression & 0.792051 & Akaike info criterion & 2.715156 \\
Sum squared resid & 71.12587 & Schwarz criterion & 2.532371 \\
Log likelihood & -158.0025 & Hannan-Quinn criter. & 2.165776 \\
F-statistic & 52.09754 & Durbin-Watson stat & 1.729033 \\
Prob(F-statistic) & 0.000000 & & \\
\hline \hline
\end{tabular}

Sumber: Data diolah dengan Eviews 7 (2020)

Berdasarkan tabel di atas diperoleh nilai F-hitung $(52,098)<$ F-tabel $(3,33)$ dan nilai probabilitas $0,0000<0,05$. Dengan demikian $\mathrm{H}_{0}$ ditolak dan $\mathrm{H}_{3}$ diterima yang berarti pendapatan rumah tangga dan pengeluaran rumah tangga secara simultan berpengaruh signifikan terhadap stabilitas keuangan rumah tangga.

Pada tabel di atas, nilai $\mathrm{R}^{2}$ yang disesuaikan adalah 0,8341 atau $83,41 \%$. Artinya $83,41 \%$, variabel stabilitas keuangan rumah tangga dapat dijelaskan oleh variasi dua variabel bebas yaitu pendapatan rumah tangga dan pengeluaran rumah tangga. Sedangkan sisanya $100 \%-83,41 \%=16,59 \%$ dijelaskan oleh penyebab lain di luar model atau variabel lain yang belum diteliti dalam penelitian ini.

\section{Pembahasan}

\section{Pengaruh pendapatan rumah tangga terhadap stabilitas keuangan rumah tangga}

Secara parsial pendapatan rumah tangga berpengaruh signifikan terhadap stabilitas keuangan rumah tangga. Hal ini dikarenakan para pelaku wirausaha yang ada di objek wisata Danau Cipondoh memiliki pendapatan yang tinggi karena setiap hari selalu ada pemasukan uang karena berwirausaha. Pendapatan tersebut, mereka gunakan untuk keperluan penting seperti membayar tagihan listrik dan air, anak sekolah, makanan, minuman dan kebutuhan rumah tangga lainnya. Setelah itu mereka mengalokasikan pendapatannya untuk membayar angsuran kredit rumah dan sepeda motor serta untuk berwisata, apabila ada sisa pendapatan mereka gunakan untuk menabung. Sehingga pendapatan yang dimiliki mereka berdampak pada stabilitas keuangan rumah tangganya karena sebagian besar pendapatan mereka sangat mempengaruhi dari jumlah pengeluaran, daya beli barang/jasa dan uang yang akan ditabung. Menurut Nababan (2013) dan Purwidianti \& Mudjiyanti (2016), semakin besar pendapatan seseorang, maka akan semakin tinggi taraf hidup seseorang. Namun demikian, kestabilan keuangan rumah tangga pada pelaku wirausaha di objek wisata Danau Cipondoh tergantung dari pelaku rumah tangga tersebut, dapat atau tidak mereka untuk bisa mengatur keuangan rumah tangganya. 


\section{Pengaruh pengeluaran rumah tangga terhadap stabilitas keuangan rumah tangga}

Secara parsial pengeluaran rumah tangga berpengaruh signifikan terhadap stabilitas keuangan rumah tangga. Hal ini karena para pelaku wirausaha di obyek wisata Danau Cipondoh mampu memenuhi kebutuhan primer dan sekunder bahkan memenuhi kebutuhan tersier. Menurut Trisnaningsih \& Widyasari (2010) dan Dwiastanti (2018), pengeluaran rumah tangga yang besar dan semakin meningkat bagi rumah tangga akan menjadi masalah keuangan rumah tangga, oleh karena itu pengeluaran rumah tangga yang berlebihan perlu dikendalikan karena pengeluaran harus disesuaikan dengan jumlah pendapatan yang terima. Karena pelaku wirausaha di obyek wisata Danau Cipondoh dapat mengelola keuangan rumah tangga yang baik, maka mereka memiliki keuangan rumah tangga yang lebih stabil dengan meminimalisir pengeluaran yang tidak terkendali, pengeluaran impulsif akibat hutang. Selain itu mereka juga harus dapat membelanjakan pengeluaran rumah tangganya secara selektif agar pengeluaran rumah tangga yang tidak terduga tidak keluar yang biasanya membuat rumah tangga semakin boros, dengan cara ini para rumah tangga juga bisa lebih berhemat. Mereka juga dapat mengetahui pengeluaran mana yang kurang dibutuhkan dan dapat memelihara tabungan. Nantinya, uang tabungan ini bisa dialokasikan untuk hal lain seperti melunasi hutang jika ada, atau digunakan untuk membiayai dana darurat suatu saat nanti.

\section{KESIMPULAN DAN SARAN}

Pendapatan rumah tangga parsial berpengaruh signifikan terhadap stabilitas keuangan dalam rumah tangga karena sebagian besar pendapatan akan sangat berpengaruh terhadap jumlah pengeluaran, daya beli barang dan tabungan, semakin besar pendapatan tabungan seseorang maka akan semakin tinggi pula taraf hidup. Pengeluaran rumah tangga parsial berpengaruh signifikan terhadap stabilitas keuangan dalam rumah tangga karena semakin besar dan meningkatnya pengeluaran rumah tangga pada pelaku wirausaha di objek wisata Danau Cipondoh akan menjadi masalah keuangan rumah tangga, sehingga perlu dilakukan pengendalian pengeluaran rumah tangga yang berlebihan. karena pengeluaran pasti tidak terkalahkan dengan jumlah pendapatan yang diterima

Pelaku wirausaha di obyek wisata Danau Cipondoh harus dapat membantu keuangan rumah tangganya dengan menjumlahkan semua pendapatan rumah tangga untuk mengetahui semua dana yang bisa dialokasikan untuk setiap kebutuhan primer, sekunder dan tersier. Setelah menghitung pendapatan, perkirakan pengeluaran rumah tangga mulai 
dari biaya makan dan minum, transportasi, pembayaran rekening listrik, air, sewa rumah, hutang dan pengeluaran rutin lainnya. Kemudian menyisihkan 25 persen dari total pendapatan untuk tabungan, asuransi, dan investasi. Tabungan dapat digunakan untuk pengeluaran yang tak terduga. Sedangkan kesehatan dilindungi oleh asuransi dan investasi yang berguna agar uang tidak habis begitu saja. Jika sudah mengalokasikan uang untuk item anggaran penting di atas, dan ternyata masih ada sisa uang, maka rumah tangga akan mengalokasikan dana untuk kebutuhan sekunder dan tersier.

Saran untuk pelaku wirausaha di obyek wisata Danau Cipondoh harus mengatur keuangan rumah tangganya meliputi kalkulasi seluruh pendapatan, menyusun rencana pengeluaran prioritas dalam sebulan, menglokasikan untuk tabungan, siapkan dana cadangan untuk keperluan mendesak, bedakan kebutuhan dan keinginan, jaga rasio pengeluaran tidak melebihi $30 \%$ dari pendapatan rumah tangga karena jika lebih dari itu, maka pendapatan rumah tangga akan habis untuk membayar pengeluaran.

Saran untuk pemerintah adalah berupaya menciptakan banyak lapangan kerja agar masyarakat hidup lebih sejahtera dengan berpenghasilan dan dapat memenuhi kebutuhan hidupnya. Kemudian pemerintah harus dapat memelihara stabilitas nilai rupiah terhadap mata uang asing yang diukur melalui sistem kurs mata uang, dan nilai rupiah terhadap harga komoditi yang diukur melalui tingkat inflasi. Selanjutnya pemerintah juga harus menjaga ketersediaan barang, kelancaran distribusi serta penetapan harga komoditi

\section{DAFTAR PUSTAKA}

Amanaturrohim, H., \& Widodo, J.(2016). Pengaruh Pendapatan dan Konsumsi Rumah Tangga Terhadap Kesejahteraan Keluarga Petani Penggarap Kopi di Kecamatan Candiroto Kabupaten Temanggung.Economic Education Analysis Journal, 5(2), 468-479.

Arnesih. (2016). Strategi Manajemen Keuangan Dalam Rumah Tangga (Berbasis Ekonomi Syariah). Historia, 10, 1-11.

Afrida, B. K. (2005). Ekonomi Sumber Daya Manusia. Jakarta: Ghalia Indonesia.

Devita, G., Swantari, A., \& Ratnaningtyas, H. (2020). Penyuluhan Pembukuan Sederhana Kepada Ibu Rumah Tangga yang Memiliki Usaha di Desa Cipasung, Kabupaten Kuningan-Jawa Barat. Jurnal Pemberdayaan Pariwisata, 2(2), 97-103.

Dwiastanti, A. (2018). Pengetahuan Keuangan Untuk Membentuk Perilaku Keuangan Keluarga (Studi Kasus Pada Ibu Rumah Tangga di Kota Malang). Majalah Ekonomi Telaah Manajemen, Akuntansi dan Bisnis, 23(1), 1-15.

Gilarso, T. (2008). Pengantar Ilmu Ekonomi Makro. Yogyakarta: Kanisius. 
Hatidjah, S., Sulfaidah \& Musdalifah. (2017). Analisis Strategi Pengelolaan Keuangan Rumah Tangga di Kota Makassar. Jurnal Economix, 5(2), 7-11.

Junandar, L. (2004). Kehidupan Pemulung. Jakarta: Rineka Cipta.

Mankiw, G. (2007). Makroekonomi. Jakarta: Erlangga.

Manullang. 2004. Pengantar Ekonomi Perusahaan. Yogyakarta: Liberty.

Masithoh, F. N., Wahyono, H. Wardoyo, C. (2016). Konsep Pengelolaan Ekonomi Rumah Tangga Dalam Memajukan Kesejahteraan. National Conference On Economic Education, 530-542.

Nababan, S. S. M. (2013). Pendapatan Dan Jumlah Tanggungan Pengaruhnya Terhadap Pola Konsumsi PNS Dosen Dan Tenaga Kependididkan Pada Fakultas Ekonomi Dan Bisnis Universitas Sam Ratulangi Manado. Jurnal EMBA, 1(4), 2130-2141.

OJK. (2020). Perencanaan Keuangan Keluarga. Jakarta: Otoritas Jasa Keuangan.

Purwidianti, W., \& Mudjiyanti, R. (2016). Analisis Pengaruh Pengalaman Keuangan Dan Tingkat Pendapatan Terhadap Perilaku Keuangan Keluarga Di Kecamatan Purwokerto Timur. BENEFIT Jurnal Manajemen dan Bisnis, 1(2), 141-148.

Rakhmawati, I., \& Suhadi. (2017). Daya Tahan Sektor Rumah Tangga Dalam Rangka Menjaga Stabilitas Sistem Keuangan. Bisnis, 5(1), 65-92.

Ratnaningtyas, H., \& Swantari, A. (2021). Pelatihan Manajemen Keuangan Pada Pelaku Wirausaha di Objek Wisata Danau Cipondoh, Kota Tangerang. Jurnal Pemberdayaan Pariwisata, 3(1), 39-44.

Rosyidi, S. (2009). Pengantar Teori Ekonomi. Jakarta: PT. Raja Grafindo.

Tigau, R., Rotinsulu, D. Ch., \& Wauran. P. C. (2017). Analisis Pendapatan dan Pola Konsumsi Pekerja Sektor Informal di Bukit Kasih Desa Kanonang Dua Kecamatan Kawangkoaan Barat. Jurnal Berkala Ilmiah Efisiensi, 17(1), 124-133.

Trisnaningsih, S., \& Widyasari, F. (2010). Manajemen Pengelolaan Dan Perencanaan Keuangan Keluarga Pada Ibu Rumah Tangga Di Kawasan Siwalan Kerto Surabaya. Jurnal Strategi Akuntansi, 2(1), 1-32.

Sugiyono. 2016. Metode Penelitian Kuantitatif, Kualitatif dan R\&D. Bandung: CV Alfabeta. 